\title{
PENGEMBANGAN MULTIMEDIA PEMBELAJARAN INTERAKTIF PENDIDIKAN AGAMA ISLAM MATERI TATA CARA SHOLAT UNTUK SEKOLAH DASAR
}

\author{
Zinnurain, Abdul Gafur \\ IKIP Mataram, Faklutas Ilmu Sosial UNY \\ zinnu_rain@yahoo.com, agafur68@gmail.com
}

\begin{abstract}
Abstrak
Penelitian ini bertujuan untuk: (1) menghasilkan multimedia pembelajaran PAI materi tata cara sholat yang layak digunakan untuk siswa sekolah dasar ditinjau dari aspek materi, pembelajaran, tampilan dan pemrograman; (2) mengetahui respons siswa dan (3) mengetahui efektifitasnya dalam pembelajaran. Penelitian ini merupakan research and development (R\&D). Subjek dalam penelitian ini adalah siswa kelas II SDN Samirono, Sleman, Yogyakarta. Uji validitas multimedia dilakukan oleh ahli materi, ahli media dan guru. Hasil penelitian adalah sebagai berikut. (1) Produk multimedia pembelajaran PAI materi tata cara sholat ini layak atau valid, terbukti dari penilaian ahli materi terhadap aspek materi dengan kategori sangat baik $(4,3)$ dan aspek pembelajaran berkategori baik $(3,83)$, sedangkan penilaian ahli media terhadap multimedia pembelajaran yang dikembangkan, aspek tampilan berkategori sangat baik $(4,2)$ dan aspek pemrograman berkategori sangat baik (4.4). Berdasarkan penilaian dari guru, aspek materi berkategori sangat baik $(4,6)$, aspek pembelajaran berkategori sangat baik $(4,08)$, aspek tampilan berkategori sangat baik $(4,45)$ dan aspek pemrograman berkategori baik $(3,8)$. (2) Respon siswa terhadap multimedia yang dikembangkan sangat baik $(95,51 \%)$. (3) Keefektifan multimedia pembelajaran yang dikembangkan termasuk dalam kategori "tinggi", hal ini ditunjukkan dari rerata kenaikan skor seluruh siswa sebesar 0,71 .
\end{abstract}

Kata kunci: pengembangan, multimedia, tata cara sholat

\section{DEVELOPING INSTRUCTIONAL MULTIMEDIA OF ISLAMIC EDUCATION FOCUSING ON SUBJECT MATTER OF PRAYER PROCEDURES FOR STUDENTS OF ELEMENTARY SCHOOL}

\author{
Zinnurain, Abdul Gafur \\ IKIP Mataram, Faklutas Ilmu Sosial UNY \\ zinnu_rain@yahoo.com, agafur68@gmail.com
}

\begin{abstract}
This research aims to: (1) develop a multimedia of Islamic education focusing on the subject matter of prayer procedures which is appropriate for Islamic instruction for grade II students of state elementary school in terms of content, instructional aspect, display aspect, and programming aspect; (2) determine the students' responses; and (3) determine its effectiveness in instructional processes. This research is research and development. The subjects were 29 second grade students of State Elementary School Samirono, Sleman, Yogyakarta. The validation of the multimedia by a matterial expert, media expert and teacher. The results are as follows. (1) The assessment of the material expert on depeloved multimedia shows that in terms of the material aspects it is very good (4.3), and the learning aspect is good (3.83), while based on media expert assessment, the display aspect is very good (4.2), and programming aspect is very good (4.4). Based on the assessment of teacher, the material aspect is very good (4.6), the learning aspect is very good (4.08), the display aspect is very good (4.45), and programming aspect is good (3.8). (2) Students' responses to the developed multimedia are very good (95.51\%). (3) The effectiveness of the developed instructional multimedia is in the "high" criterion, which can be seen from the average gain score of all students in grade II which is 0.71 .
\end{abstract}

Keywords: development, multimedia, prayers procedures 


\section{Pendahuluan}

Sholat merupakan tiang agama. Sholat juga merupakan amalan yang pertama kali akan dihisab di hari kiamat. Apabila baik sholatnya, baik pula amalnya yang lain. Dalam upaya mengenalkan sholat yang baik dan benar sesuai dengan ajaran Rasulullah SAW, maka sholat sejatinya hendaklah diajarkan kepada anak sejak usia dini. Dalam kurikulum pendidikan sekolah dasar, sholat adalah salah satu kompetensi yang harus dikuasai oleh para siswa sekolah dasar yang mulai dipelajari sejak kelas 1 semester 2 sampai kelas 6 semester 2. Pengertian sholat dalam syariat Islam ialah ibadah yang tersusun dari perkataan dan perbuatan yang dimulai dari takbir dan diakhiri salam, serta memenuhi beberapa syarat yang ditentukan (Daradjat, 1996, pp. 33-34).

Penggunaan media pembelajaran berbantuan komputer merupakan salah satu contoh pemanfaatan TIK dalam pendidikan. Media pembelajaran berbantuan komputer berguna untuk mengurangi batasan ruang dan waktu. Dalam proses kegiatan belajar mengajar, salah satu faktor yang mempengaruhi pencapaian tujuan pembelajaran adalah dengan pemilihan media pembelajaran yang tepat untuk mencapai kompetensi pembelajaran yang diharapkan.

Pada kenyataannya selama ini penjelasan materi sholat cenderung menggunakan metode ceramah. Akibatnya materi tata cara sholat yang disampaikan menjadi abstrak, siswa baru bisa memahami materi tata cara yakni setelah kegiatan praktek dilakukan. Namun demikian, kegiatan praktek ini jarang dilakukan dikarenakan terbatasnya waktu untuk pembelajaran materi tata cara sholat. Adanya multimedia pembelajaran tata cara sho-lat akan lebih memudahkan siswa da-lam mempelajari gerakan sholat.

Sholat adalah materi pelajaran yang menekankan pada keterampilan praktek. Berdasarkan pra-survey yang dilakukan peneliti di SD N Samirono, diketahui bah- wa selama ini penjelasan materi sholat cenderung menggunakan metode ceramah yang diterapkan dalam proses belajar mengajar yang diselenggarakan oleh guru mata pelajaran pendidikan agama Islam. Akibatnya materi tata cara sholat yang disampaikan menjadi abstrak, siswa baru bisa memahami materi tata cara yakni setelah kegiatan praktek dilakukan. Namun demikian, kegiatan praktek ini jarang dilakukan dikarenakan terbatasnya waktu untuk pembelajaran materi tata cara sholat.

Salah satu faktor yang menyebabkan belum meningkatnya kualitas pembelajaran adalah belum dimanfaatkannya sumber belajar atau media dengan maksimal. Terbatasnya pemanfaatan TIK dalam pembelajaran di kelas diduga merupakan salah satu sebab lemahnya mutu pendidikan pada umumnya. Hal ini terlebih sangat dirasakan pada mata pelajaran keagamaan. Pemanfaatan media dalam proses pembelajaran pendidikan agama Islam di SD N Samirono belum optimal. Salah satunya adalah belum adanya multimedia pembelajaran interaktif pendidikan agama Islam materi tata cara sholat untuk kelas 2 sekolah dasar yang interaktif dan menarik.

Peneliti menganggap bahwa sangat perlu dilakukan pengembangan desain dan model pembelajaran yang inovatif dan interaktif, seperti model pembelajaran yang didesain dengan mengembangkan multimedia pembelajaran. Pengembangan multimedia pembelajaran tata cara sholat pada mata pelajaran pendidikan agama Islam untuk kelas 2 sekolah dasar menjadi salah satu solusi dalam rangka mencapai tujuan pendidikan yang diharapkan yakni meningkatkan kualitas pembelajaran.

Berdasarkan hal-hal tersebut, maka sangat perlu dilakukan pengembangan desain dan model pembelajaran yang inovatif dan interaktif. Pengembangan multimedia pembelajaran tata cara sholat pada mata pelajaran pendidikan agama Islam untuk kelas 2 sekolah dasar menjadi salah satu solusi dalam rangka mencapai tujuan pendidikan yang diharapkan yakni meningkatkan kualitas pembelajaran. 
Tujuan utama dalam penelitian dan pengembangan media pembelajaran ini adalah untuk: (1) menghasilkan multimedia pembelajaran pendidikan agama Islam materi tata cara sholat yang layak dan valid dengan memanfaatkan media berbasis IT yang telah tersedia di ruang laboratorium, (2) mengetahui respons siswa terhadap produk yang dikembangkan, dan (3) mengetahui keefektifan produk yang dikembangkan dalam proses pembelajaran pendidikan agama Islam.

Multimedia diartikan sebagai suatu penggunaan gabungan beberapa media dalam menyampaikan informasi yang berupa teks, grafis atau animasi grafis, movie, video dan audio. Multimedia interaktif yang meliputi hypermedia dan hypertext. Hypermedia yaitu suatu penggunaan format presentasi multimedia yang meliputi teks, grapis, animasi, bentuk movie, video dan audio. Hypertext yaitu bentuk teks, diagram statis, gambar dan tabel yang ditanyangkan dan disusun secara tidak linier (urut atau garis).

Menurut Agnew, Kellerman \& Meyer (1996,p. 8) istilah multimedia lebih terfokus pada interaktifitas antara media dengan pemakai media, sehingga tidak hanya diartikan sebagai penggunaan banyak media. Penggabungan semua elemen multimedia akan dapat menanamkan pemikiran dan aksi dalam pikiran orang lain.

Multimedia pembelajaran merupakan komponen yang dapat digunakan dalam mendukung proses pembelajaran. Hal ini dilandasi oleh persepsi bahwa pembelajaran akan berlangsung efektif, dan menyenangkan jika didukung oleh animasi gambar yang dapat menarik minat dan perhatian siswa. Multimedia berbantuan komputer mampu memberikan retensi yang lebih kuat dalam proses pembelajaran (Karra, 2008, p. 362). Pembelajaran yang melibatkan multimedia memberikan peluang kepada siswa untuk lebih berpartisipasi aktif karena siswa lebih diberi kesempatan berhadapan secara langsung dengan komputer.

Keunggulan-keunggulan penggunaan media pembelajaran berbantuan kom- puter adalah: (1) dapat mengubah dari halhal yang bersifat abstrak menjadi konkrit, (2) dapat menyederhanakan permasalahan yang kompleks, (3) mampu menampilkan proses pembelajaran yang interaktif, karena siswa dapat belajar sesuai dengan keinginan dan kemampuannya, (4) mampu mengurangi biaya yang mahal dan resiko yang tinggi bila menggunakan objek nyata dalam pembelajaran, (5) melalui pembelajaran dapat dilakukan secara berulangulang sehingga siswa tidak merasa malu bertanya bila belum menguasai, karena komputer tidak akan merasa jenuh, dan (6) dapat dilakukan secara mandiri sehingga dapat dilakukan dimana saja dan kapan saja, tidak terikat ruang dan waktu.

Menurut Heinich, et.al. (1996, pp. 238-242) terdapat enam bentuk yang biasanya digunakan untuk menggambarkan pembelajaran berbantuan komputer yaitu drill and practice, tutorial, games, simulations, discovery dan problem solving. Adapun multimedia pembelajaran tata cara sholat yang dikembangkan masuk ke dalam bentuk tutorial dan simulation. Bentuk tutorial digunakan untuk menggambarkan bahwa siswa bisa langsung berinteraksi dengan media dimana media sebagai sumber informasi seolah-olah menjadi tutor dalam memberikan pembelajaran sedangkan simulation digunakan karena dalam multimedia pembelajaran yang dikembangkan, materi disajikan menggunakan animasi bergerak untuk menggambarkan gerakan semirip mungkin dengan praktek nyata yang biasa dilakukan.

Analisis kebutuhan produk digunakan dalam prosedur pengembangan produk serta perlu dilakukan uji keefektifan produk. Borg \& Gall membagi prosedur pengembangan ke dalam sepuluh langkah. Untuk mengetahui kriteria kualitas multimedia pembelajaran dapat dilihat dari tiga aspek umum yaitu aspek pembelajaran, aspek materi, dan aspek media. Ketiga aspek tersebut tidak dapat dipisahkan dalam proses pembelajaran dengan menggunakan multimedia pembelajaran karena merupakan satu kesatuan yang mendukung. 
Keefektifan berkaitan dengan terlaksananya semua tugas, tercapainya tujuan dan adanya ketepatan waktu. Keefektifan pembelajaran dapat dilihat dari dua aspek yaitu aspek mengajar guru, dan aspek belajar siswa. Pembelajaran dengan menggunakan media bisa dikatakan efektif apabila media yang digunakan bisa menjadikan tujuan pembelajaran lebih tercapai dan memudahkan siswa dalam belajar.

Penggunaan sumber belajar juga akan menentukan efisiensi suatu media pembelajaran. Sumber belajar terkait dengan sarana dan prasarana dalam pembelajaran. Semakin sedikit waktu yang digunakan, personalia yang terlibat dan sumber belajar yang diperlukan tetapi pencapaian tujuan pembelajaran lebih banyak maka pembelajaran tersebut dikatakan efisien.

Salah satu bentuk karakteristik yang dimiliki teknologi berdasar komputer menurut Seels \& Richey (1994, p. 40) adalah belajar yang berpusat pada siswa dan menghendaki kegiatan pembelajaran yang sangat interaktif. Karakteristik ini dapat membantu pembelajaran individual. Di dalam kawasan pengembangan terdapat keterkaitan kompleks antara teknologi dan teori yang mendorong baik desain, pesan, maupun strategi pembelajaran. Dalam hal ini pengembangan multimedia pembelajaran yang merupakan kegiatan pemanfaatan teknologi, khususnya dalam fungsi pengembangan sumber belajar pada tahapantahapan tertentu. Sehingga hambatan belajar terutama yang berkaitan dengan keterbataasan sumber belajar diharapkan dapat teratasi.

Belajar erat kaitannya dengan perubahan tingkah laku. Dengan belajar maka pengetahuan, keterampilan, kebiasaan, nilai, sikap, tingkah laku, dan semua perbuatan manusia dapat terbentuk, disesuaikan dan dikembangkan. Teori-teori belajar mempunyai implikasi yang luas dalam konteks pembelajaran, khususnya dalam aspek sumber belajar dan pendekatan pembelajaran dalam proses pendidikan. Dengan memahami beberapa teori belajar, maka teori tersebut dapat dimanfaatkan untuk mensistemasikan penemuan-penemuan, memprediksi, melahirkan hipotesishipotesis, dan dapat memberikan penjelasan-penjelasan sesuai dengan kebutuhan.

Teori behavioristik memandang belajar sebagai perubahan tingkah laku sebagai akibat adanya interaksi stimulus dan respon. Hal yang dapat mempengaruhi stimulus dan respon adalah penguatan (reinforcement) yaitu apa saja yang dapat memperkuat timbulnya respon. Aktifitas pembelajaran seperti pembelajaran berbantuan komputer dapat mengubah sikap siswa dengan cara yang dapat diukur dan dilihat dengan jelas perubahannya. Dapat dikatakan bahwa perubahan tingkah laku siswa akibat dari motivasi yang diberikan dalam proses pembelajaran. Teori behavioristik diterapkan pada multimedia pembelajaran yang dikembangkan dengan mengacu pada materi dikembangkan secara terstruktur dalam bentuk frame-frame animasi, ada respon dan balikan segera atas aktifitas saat siswa menjalankan multimedia pembelajaran dalam bentuk balikan atas jawaban pada latihan, dan multimedia dikembangkan mengacu pada self pacing (siswa dapat belajar secara mandiri sesuai tingkat kemampuan dan kecepatannya sendiri).

Teori konsistensi kognitif berpendapat bahwa hasil motivasi terjadi karena adanya kognitif dan behavior yang saling mempengaruhi. Teori kognitif berpendapat bahwa tingkah laku seseorang ditentukan oleh persepsi serta pemahamannya tentang situasi yang berhubungan dengan tujuan belajarnya.

Teori belajar kognitif merupakan suatu bentuk teori belajar yang sering disebut sebagai model perceptual, yaitu tingkah laku seseorang ditentukan oleh persepsi dan pemahamannya tentang situasi yang berhubungan dengan tujuan belajarnya. Implikasi teori kognitif dalam multimedia pembelajaran yang dikembangkan yaitu terletak pada pemilihan komponen-komponen dalam pengembangan produk. Materi pembelajaran tata cara sholat disusun dan dikembangkan dengan 
menggunakan pola berupa full animasi bergerak yang dilengkapi dengan pemilihan audio yang ceria, penjelasan berbentuk narasi, pemilihan warna-warna terang dan menarik yang kesemuanya disesuaikan dengan karakteristik siswa. Penyusunan latihan yang melibatkan siswa untuk aktif dalam menjalankan program berangkat dari asumsi bahwa siswa merupakan pembelajar kognitif level operasional konkrit yang masih terbatas pada objek-objek konkrit.

Pendidikan Agama Islam berarti usaha-usaha secara sistematis dan pragmatis dalam membantu anak didik agar mereka hidup sesuai dengan ajaran Islam. Pendidikan Islam dalam perannya tidak hanya bersifat teoritis saja, tetapi juga menyentuh area praktis. Mata pelajaran Pendidikan Agama Islam secara keseluruhannya dalam lingkup Al-Qur'an dan AlHadits, keimanan, akhlak, fiqh/ibadah, dan tarikh/sejarah. Dalam Nasih \& Kholidah (2009, pp. 16-17), dijelaskan bahwa pendidikan agama Islam seperti disebutkan di atas juga mencerminkan setidaknya empat nilai, yaitu:

Pertama, nilai material adalah jumlah pengetahuan agama Islam yang diajarkan. Semakin lama siswa belajar semakin bertambah ilmu pengetahuan agamanya. Kedua, nilai formal adalah nilai pembentuk yang berkaitan dengan daya serap siswa atas segala bahan yang telah diterimanya. Melalui pengalaman kejiwaan akan terjadi pembentukan berbagai daya rohani yang menjadi kepribadian seseorang. Ketiga, nilai fungsional adalah relevansi bahan ajar dengan kehidupan seharihari. Ditinjau dari segi tuntutan agama, jelas bahwa ajaran itu harus dilaksanakan atau dipakai dalam kehidupan sehari-hari. Keempat, nilai esensial, adalah nilai hakiki. Agama mengajarkan bahwa kehidupan yang hakiki adalah kehidupan yang bermakna baik di dunia maupun di akhirat. Adapun nilai-nilai yang hakiki dapat berupa nilai pembersih atau penyucian jiwa dan nilai kesempurnaan akhlak.
Kurikulum pendidikan agama Islam untuk sekolah/madrasah memiliki fungsi dan tujuan sebagai berikut: (1) pengembangan iman taqwa, (2) penanaman nilai, (3) penyesuaian mental, (4) perbaikan, (5) pencegahan, (6) pengajaran, dan (7) penyaluran.

Sholat adalah merupakan pangkal tolak pembinaan kepribadian seseorang muslim. Peningkatan pembiasaan sholat itu merupakan hal yang urgent untuk diterapkan kepada siswa, yakni bagaimana memotivasi siswa untuk membiasakan sholat lima waktu, bagaimana mengelola waktu yang singkat untuk tatap muka tapi efektif dan efesien dalam membina mereka, sehingga siswa tidak hanya mampu menguasai materi sholat secara teoritis saja melainkan mampu mendirikan ibadah sholat (kemampuan operasional).

Materi tata cara sholat pada sekolah dasar selama ini penyajiannya belum terlalu mendalam dan sempurna. Ini dikarenakan waktu yang tidak cukup serta belum adanya media yang mampu dipergunakan dan dimanfaatkan secara maksimal di dalam pembelajaran tersebut. Untuk itulah diperlukan usaha untuk mengembangkan multimedia tentang materi tata cara sholat untuk siswa kelas 2 sekolah dasar agar siswa dengan mudah menerima materi pembelajaran dan pada akhirnya tujuan pembelajaran pendidikan agama islam akan tercapai dengan baik dan optimal.

Masa usia sekolah dasar sebagai masa kanak-kanak akhir yang berlangsung dari usia enam tahun hingga kira-kira dua belas tahun. Anak-anak pada umur antara 6-12 tahun, ditandai dengan perkembangan kecerdasan cepat. karakteristik utama siswa sekolah dasar adalah mereka menampilkan perbedaan-perbedaan individual dalam banyak segi dan bidang, diantaranya adalah perbedaan dalam intelegensi, kemampuan dalam kognitif dan bahasa, perkembangan kepribadian dan perkembangan fisik anak. Piaget mengidentifikasikan tahapan perkembangan intelektual yang dilalui anak yaitu: (a) tahap sensorik motor usia 0-2 tahun, (b) tahap praopera- 
sional usia 2-6 tahun, (c) tahap operasional kongkrit usia 7-11 atau 12 tahun, dan (d) tahap operasional formal usia 11 atau 12 tahun ke atas.

Anak usia sekolah dasar tertarik terhadap pencapaian hasil belajar. Mereka mengembangkan rasa percaya dirinya terhadap kemampuan dan pencapaian yang baik dan relevan. dalam penyampaian materi pelajaran pendidikan agama Islam di sekolah dasar harus disesuaikan dengan karakteristik dan perkembangan jiwa siswa sekolah dasar yakni level operasional konkrit, metode dan strategi yang tepat sehingga membantu siswa dalam mencapai tujuan pembelajaran yang diharapkan, yaitu dengan cara, mengembangkan produk multimedia pembelajaran dengan penggunaan warna yang mampu menarik perhatian siswa, konten animasi bergerak berupa simulasi gerakan sholat dan narasi berupa penjelasan tentang gerakan sholat yang didengar langsung oleh user dalam hal ini siswa kelas 2 sekolah dasar.

Dalam upaya memberikan pembelajaran pada materi tata cara sholat yang interaktif dan bermakna adalah dengan mengembangkan multimedia pembelajaran PAI materi tata cara sholat dimana merupakan salah satu model pembelajaran yang aktifitasnya memanfaatkan media komputer. Multimedia pembelajaran dimanfaatkan guna menyalurkan pesan (pengetahuan, keterampilan dan sikap) serta dapat merangsang pikiran, perasaan, perhatian dan kemauan siswa sehinga secara sengaja proses belajar berlangsung, bertujuan dan terkendali. Dengan demikian, proses pembelajaran yang terjadi akan lebih interaktif, efektif dan menarik/menyenangkan.

\section{Metode Penelitian}

Jenis, Waktu, dan Prosedur Penelitian

Penelitian ini adalah penelitian dan pengembangan (research and development). Borg \& Gall (1983, p.775) memberikan sepuluh langkah prosedural dalam penelitian dan pengembangan, yaitu: (1) melakukan pengumpulan informasi, (2) melakukan perancangan, (3) mengembangkan bentuk produk awal, (4) melakukan uji coba terbatas, (5) melakukan revisi, (6) melakukan uji coba lapangan, (7) melakukan revisi, (8) melakukan uji lapangan operasional, (9) melakukan revisi terhadap produk akhir, dan (10) mendesiminasikan dan mengimplementasikan produk. Pada penelitian ini, peneliti hanya melaksanakan langkah (1) sampai dengan (7) saja karena hasil penelitian ini tidak disebarluaskan pada sekolah lain.

Penelitian ini dilakukan pada 6 Juni 2014 di SD N Samirono, Sleman, Yogyakarta. Prosedur pengembangan yang digunakan dalam pengembangan multimedia pembelajaran PAI ini adalah gabungan prosedur yang diadopsi dari langkah pengembangan Borg \& Gall dan langkah pengembangan Owens \& Lee. Prosedur pengembangan dan penelitian ini dijelaskan secara terperinci sebagai berikut.

Pertama, analisis kebutuhan yang meliputi studi pustaka dan studi lapangan. Kedua, desain pembelajaran. Desain Dick and Carey (2001, pp.2-3) dipilih sebagai acuan model desain pembelajaran yang digunakan dalam penelitian ini yaitu dalam bentuk system aproach model for designing instruction yang terdiri dari: (1) identifikasi standar kompetensi; (2) menetapkan kompetensi; (3) identifkasi karakteristik awal siswa; (4) merumuskan indikator, memilih materi pelajaran; dan (5) menyusun strategi pembelajaran.

Ketiga, dalam penelitian ini tahap produksi/pengembangan media dilakukan melalui langkah-langkah yang dikemukakan oleh Philips (1997, p. 38) yaitu: (1) membuat fowchart; (2) mengumpulkan bahan; (3) membuat storyboard; dan (4) memasukkan materi, tes modular. Keempat, evaluasi dan revisi produk dengan tahapan sebagai berikut: (1) validasi ahli materi dan ahli media; (2) uji coba satu-satu; (3) uji coba kelompok kecil; dan (4) uji coba lapangan, pretes dan postes. Kelima, hasil produk akhir adalah multimedia pembelajaran hasil pengembangan yang siap di- 
gunakan dalam pembelajaran pendidikan agama Islam materi tata cara sholat untuk mengetahui keefektifan dan kelayakan multimedia berdasarkan kualitas hasil belajar siswa setelah menggunakan multimedia pembelajaran.

\section{Desain Uji Coba}

Uji coba adalah kegiatan evaluasi formatif yang dilakukan dengan cara meminta bantuan orang lain untuk mencoba program yang sedang dikembangkan. Tujuan uji coba adalah untuk mendapatkan umpan balik secara langsung dari calon pengguna tentang kelemahan-kelamahan kualitas produk media yang sedang dikembangkan sebagai dasar untuk melakukan revisi produk.

\section{Subjek Validasi dan Subjek Uji Coba}

Valiadasi dilakukan oleh dua orang ahli yaitu ahli materi dan ahli media sebagai subjek validasi produk.

Subjek uji coba dalam penelitian pengembangan ini adalah siswa kelas $2 \mathrm{SD}$ N Samirono. Pengambilan data dibagi sebanyak tiga kali dengan siswa yang berbeda. Sampel uji coba satu-satu terdiri atas 3 orang siswa, uji kelompok kecil 9 orang siswa dan uji lapangan dengan responden untuk kegiatan pembelajaran berjumlah 29 orang siswa.

\section{Jenis Data}

Jenis data yang diperoleh dari penelitian dan pengembangan ini ada dua jenis. Pertama, jenis data kualitatif yang diperoleh dari komentar, kesan serta tanggapan siswa, guru, ahli materi dan ahli media. Kedua, jenis data kuantitatif yang diperoleh dari hasil pengisian lembar validasi ahli materi dan ahli media, guru dan respons siswa. Data tersebut dimaksudkan untuk mengetahui kualitas dari masingmasing komponen pengembangan multimedia pembelajaran agar nantinya dapat digunakan dalam aktifitas pembelajaran. Data kuantitatif berupa skor tanggapan tentang kualitas produk baik ahli materi, ahli media, dan subjek coba dari siswa, serta data skor hasil pre-test dan post-test.

\section{Instrumen Pengumpulan Data}

Instrumen yang digunakan untuk mengumpulkan data berupa instrumen penilaian untuk menilai produk yang telah dikembangkan baik dari aspek materi, aspek pembelajaran, aspek tampilan dan pemrograman. Instrumen pengumpulan data berupa lembar validasi ahli materi dan ahli media, lembar respons siswa, lembar penilaian guru dan tes. Sesuai dengan keperluan di atas, kemudian dibuat kisi-kisi instrumen yang diambil dari beberapa konsep dari Crozat, $\mathrm{Hu}$, \& Trigano, (1999, pp.1-3) kemudian konsep tersebut disesuaikan berdasarkan kebutuhan didalam penelitian.

Tabel 1. Kisi-kisi Instrumen Ahli Materi

\begin{tabular}{clc}
\hline No & \multicolumn{1}{c}{ Aspek } & Jumlah butir \\
\hline 1. & Materi & 10 \\
2. & Pembelajaran & 12 \\
\hline
\end{tabular}

Tabel 2. Kisi-Kisi Instrumen Ahli Media

\begin{tabular}{clc}
\hline No & \multicolumn{1}{c}{ Aspek } & Jumlah butir \\
\hline 1. & Tampilan & 12 \\
2. & Pemrograman & 11 \\
\hline
\end{tabular}

Tabel 3. Kisi-kisi Instrumen Penilaian Guru

\begin{tabular}{clc}
\hline No & \multicolumn{1}{r}{ Aspek } & Jumlah Butir \\
\hline 1 & Materi & 10 \\
2 & Pembelajaran & 11 \\
3 & Tampilan & 11 \\
4 & Pemrograman & 8 \\
\hline
\end{tabular}

Tabel 4. Kisi-Kisi Respon Siswa

\begin{tabular}{clc}
\hline No & \multicolumn{1}{r}{ Aspek } & Jumlah Butir \\
\hline 1 & Materi & 7 \\
2 & Pembelajaran & 2 \\
3 & Tampilan & 3 \\
4 & Pemrograman & 3
\end{tabular}


Teknik Analisis Data

Data yang diperoleh melalui instrumen penelitian digunakan untuk menilai kualitas produk yang dikembangkan. Data berupa skor (kuantitatif) yang diperoleh akan dianalisis secara deskriptif kualitatif dengan menggunakan acuan konversi skala 5 .

Data hasil penelitian ini adalah berupa tanggapan ahli materi, ahli media dan guru terhadap kualitas produk yang dikembangkan ditinjau dari aspek isi materi, pembelajaran, tampilan dan pemrograman. Data yang berupa komentar, saran revisi dan hasil pengamatan selama proses uji coba dianalisis secara deskriptif kualitatif dan disimpulkan sebagai masukan untuk merevisi produk yang dikembangkan.

Tabel 5. Konversi skala Likert

\begin{tabular}{ccc}
\hline Nilai & Interval Skor & Data Kualitatif \\
\hline 5 & $X>x i+1,80$ Sbi & Sangat baik \\
4 & $X i+0,60$ Sbi $<X \leq x i+1,80$ Sbi & Baik \\
3 & $x i-0,60$ Sbi $<X \leq x i+0,60$ Sbi & Cukup \\
2 & $x i-1,80$ Sbi $<X \leq x i+0,60$ Sbi & Kurang \\
1 & $X \leq x i-1,80$ Sbi & Sangat Kurang \\
\hline
\end{tabular}

Keterangan :

$\begin{array}{ll}\mathrm{Xi}_{\text {(Rerata skor ideal) }} & : \begin{array}{l}1 / 2(\text { Skor mak ideal + skor } \\ \text { min ideal) }\end{array} \\ \text { Sbi (Simpangan baku ideal) }) & : 1 / 6 \text { (Skor mak ideal - } \\ & \text { skor min ideal) } \\ X & : \text { Skor Empiris (Aktual) }\end{array}$

Skor pada Tabel 4 dapat dijelaskan sebagai berikut: (1) jika rata-rata skor yang diperoleh berkisar antara 4,22 saampai 5,00 maka produk dinyatakan sangat baik; (2) Jika rata-rata skor berkisar antara 3,41 sampai 4,21 maka produk yang dikembangkan dinyatakan baik; (3) Jika rata-rata skor berkisar antara 2,61 sampai 3,40 maka produk yang dikembangkan dinyatakan cukup; (4) Jika rata-rata skor berkisar antara 1,80 sampai 2,60 maka produk yang dikembangkan dinyatakan kurang; (5) Jika rata-rata skor berkisar antara 1 sampai 1,79 maka produk yang dikembangkan dinyatakan sangat kurang.
Sedangkan untuk mengetahui keefektifan produk berupa tingkat pemahaman materi yang telah diajarkan diwujudkan dalam skor tes hasil belajar setelah menggunakan produk yang dikembangkan. Skor hasil pre-test dan post-test dianalisis dengan membandingkan skor pre-test dan post-test. Rata-rata gain yang dinormalisasi (N-gain) (Hake, 1998, p. 3) dinyatakan dengan persamaan sebagai berikut:

Keterangan:

$$
g=\frac{S_{\text {post }}-S_{\text {pre }}}{S_{\text {maks }}-S_{\text {pre }}}
$$

Spost : Skor Post-test

Spre : Skor Pre-test

Smaks : Skor Maksimal

Nilai ini selanjutnya diinterpretasikan ke dalam Tabel 6 klasifikasi Nilai Gain (Hake. 1998, p.3) berikut:

Tabel 6. Klasifikasi Nilai Gain

\begin{tabular}{c|c}
\hline Nilai & Klasifikasi \\
\hline$(\mathrm{N}$-gain $) \geq 0,7$ & Tinggi \\
$0,7>(\mathrm{N}$-gain $) \geq 0,3$ & Sedang \\
$(\mathrm{N}$-gain $)<0,3$ & Rendah \\
\hline
\end{tabular}

\section{Hasil Penelitian dan Pembahasan}

Hasil yang diperoleh dalam penelitian ini terdiri dari data penilaian ahli materi dan ahli media, data penilaian guru mata pelajaran, data respons siswa, dan pre-test dan post-test.

Data hasil validasi dan evaluasi produk ini meliputi data hasil validasi dari ahli materi dan ahli media, serta data evaluasi guru mata pelajaran. Hasil penilaian berupa skor yang dikonversi menjadi 5 kriteria.

Dalam analisis data hasil validasi produk ahli materi terdapat dua aspek yang menjadi penilaian ahli materi yaitu aspek materi dan pembelajaran. Untuk aspek materi terdapat 10 indikator penilaian, 4 indikator mendapatkan skor 5 (sangat baik), 5 indikator mendapatkan skor 4 (baik), dan 1 indikator mendapatkan skor 3 (cukup). Hasil perhitungan rerata skor pa- 
da aspek materi adalah 4,3 dengan kategori "sangat baik". Kemudian pada tabel 10 untuk aspek pembelajaran terdapat 12 aspek penilaian dengan rincian 2 indikator mendapatkan skor 5 (sangat baik), 6 indikator mendapatkan skor 4 (baik) dan 4 indikator mendapatkan skor 3 (cukup). Rerata dari aspek pembelajaran ini adalah 3,83 dengan kategori "baik". Hasil penilaian dari ahli materi untuk aspek materi dan pembelajaran jika disajikan dalam bentuk diagram dengan rata-rata skala 5 maka hasilnya adalah disajikan pada Gambar 1.

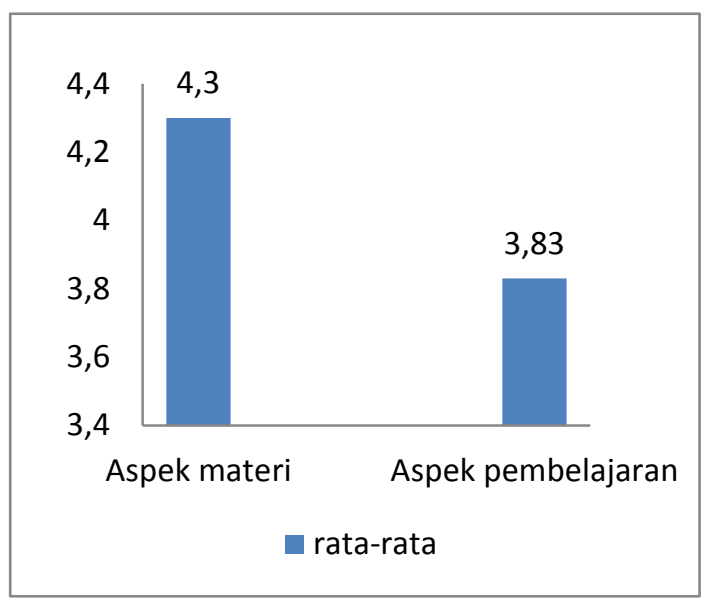

Gambar 1. Diagram Penilaian Ahli Materi

Dalam analisis hasil validasi produk ahli media ini terdapat dua aspek yang menjadi penilaian ahli media yaitu aspek tampilan dan aspek pemrograman. pada aspek tampilan terdapat 10 aspek penilaian, 3 indikator mendapatkan skor 5 (sangat baik), 6 indikator mendapatkan skor 4 (baik) dan 1 indikator mendapatkan skor 3 (cukup). Hasil perhitungan rerata skor pada aspek tampilan adalah 4,2 dengan kategori "sangat baik". Untuk aspek pemrograman terdapat 8 aspek penilaian dengan rincian 5 aspek mendapatkan skor 4 "baik" dan 3 aspek mendapatkan skor 5 "sangat baik". Rerata dari aspek tampilan ini adalah 4,4 dengan kategori "sangat baik".

Hasil penilaian dari ahli media untuk aspek tampilan dan aspek pemrograman jika disajikan dalam bentuk diagram dengan rata-rata skala 5 hasilnya adalah disajikan pada Gambar 2.

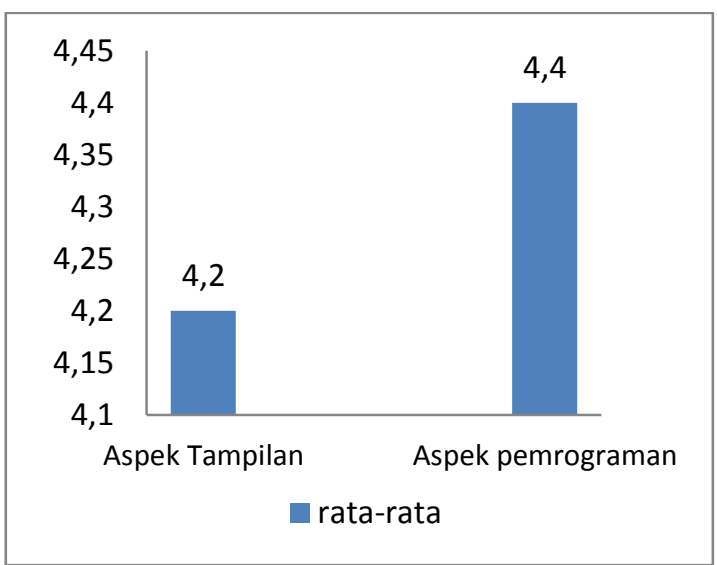

Gambar 2. Diagram Penilaian Ahli Media

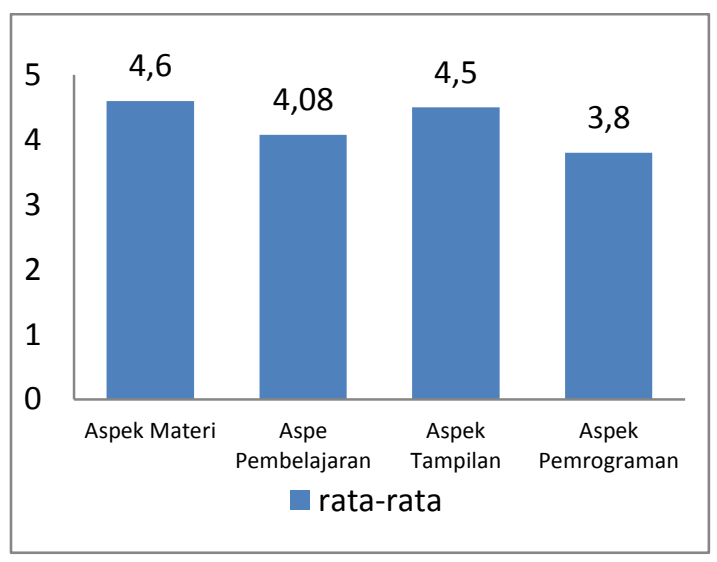

Gambar 3. Diagram Penilaian Guru

Dalam analisis data penilaian produk oleh guru atau praktisi ini terdapat empat aspek yang menjadi penilaian oleh guru yaitu aspek materi, aspek pembelajaran, aspek tampilan dan aspek pemrograman. Rerata penilaian guru untuk aspek materi adalah 4,6 dengan kategori "sangat baik" karena dari 10 indikator yang dinilai sebanyak 6 indikator mendapatkan skor 5 (sangat baik) dan 4 indikator mendapatkan skor 4 (baik). Aspek pembelajaran diperoleh rerata 4,08 dengan kategori "sangat baik", dari 12 indikator yang dinilai, 1 indikator memperoleh skor 5 (sangat baik) dan selebihnya yakni 11 indikator memperoleh skor 4 (baik). Pada aspek tampilan, berdasarkan diperoleh rerata 4,45 dengan kategori "sangat baik". Untuk 11 indikator yang dinilai, sebanyak 5 indikator memperoleh skor 5 (sangat baik) dan 6 indikator memperoleh skor 4 (baik). Sedangkan untuk aspek pemrog- 
raman rerata penilaian guru sebesar 3,8 dengan kategori "baik" karena dari 8 indikator yang dinilai sebanyak 2 indikator mendapatkan skor 5 (sangat baik), 3 indikator mendapatkan skor 4 (baik) dan 3 indikator memperoleh skor 3 (cukup). Jika disajikan dalam bentuk diagram dengan rata-rata skala 5 maka hasilnya adalah disajikan pada Gambar 3.

\section{Uji Coba Satu-satu (one-to-one)}

Informasi yang diperoleh dari uji coba satu-satu ini adalah data respons siswa terhadap multimedia pembelajaran PAI materi tata cara sholat yang dikembangkan. Data hasil respons siswa terhadap produk ditinjau dari aspek materi, pembelajaran, tampilan dan pemrograman. Data yang diperoleh kemudian dihitung persentase siswa yang memilih pilihan "ya" dan "tidak". Hasil respons siswa pada uji coba satu-satu jika disajikan dalam diagram pada Gambar 4.

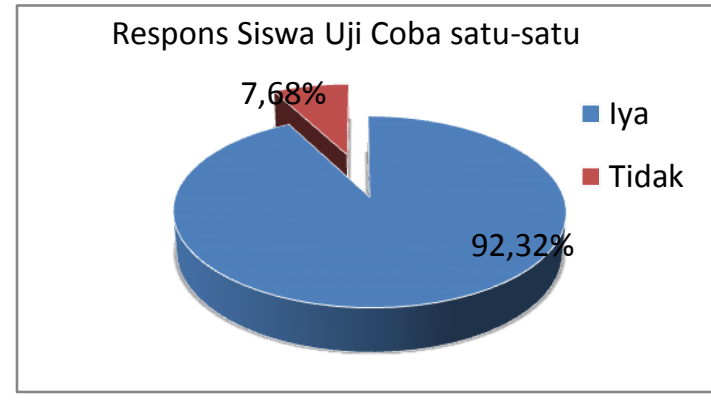

Gambar 4. Diagram Respons Siswa Uji Coba Satu-Satu

Uji Coba Kelompok Kecil (Small Group Evaluation)

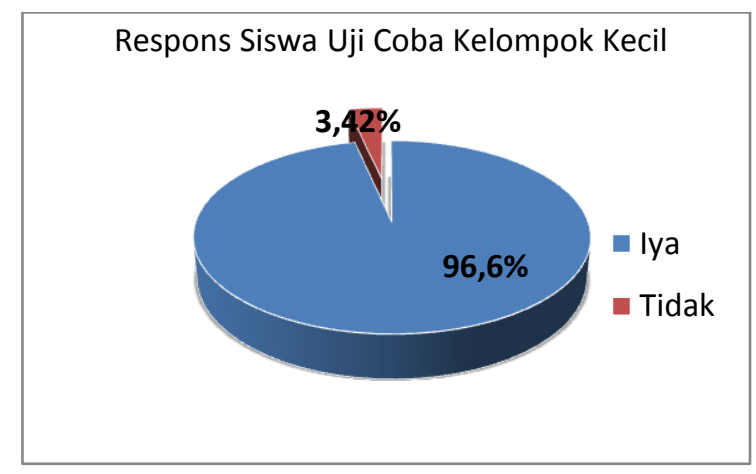

Gambar 5. Diagram Respon Siswa Uji Coba Kelompok Kecil
Informasi yang diperoleh dari uji coba kelompok kecil ini adalah data respons siswa terhadap multimedia yang dikembangkan. Hasil respons siswa pada uji coba kelompok kecil terhadap multimedia pembelajaran PAI materi tata cara sholat ini jika disajikan dalam diagram pada Gambar 5.

\section{Uji Coba Lapangan (Field Trial)}

Data yang diperoleh peneliti dalam uji coba lapangan terkumpul dalam data hasil belajar siswa dan data respons siswa terhadap produk pengembangan. Uji coba lapangan terdiri dari respons siswa serta pre-test dan post-test.

Pre-test dan Post-test dilakukan untuk menguji kemampuan kognitif siswa. Berikut analisis hasil pre-test dan post-test jika disajikan dalam diagram maka dapat disajikan sebagai berikut.

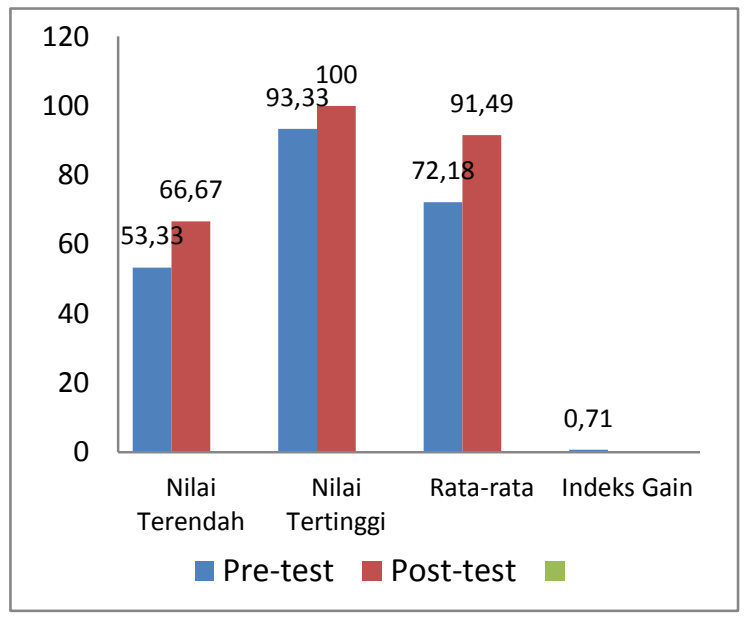

Gambar 6. Diagram Hasil Pre-Test dan Post-Test dan Rata-rata Indeks Gain

Berdasarkan Tabel 6 diketahui bahwa terjadi peningkatan hasil belajar siswa setelah mengalami proses pembelajaran. Berdasarkan hasil pre-test dan post-test yang dihitung menggunakan standar gain diketahui sebanyak 15 siswa yang termasuk dalam kategori "tinggi" sedang-kan 13 siswa termasuk dalam kategori "sedang", dan hanya 1 siswa saja yang masuk dalam kategori "rendah" dalam peningkatan hasil belajar dilihat dari skor gain yang diper- 
oleh. Berikut diagram perolehan klasifikasi gain siswa.

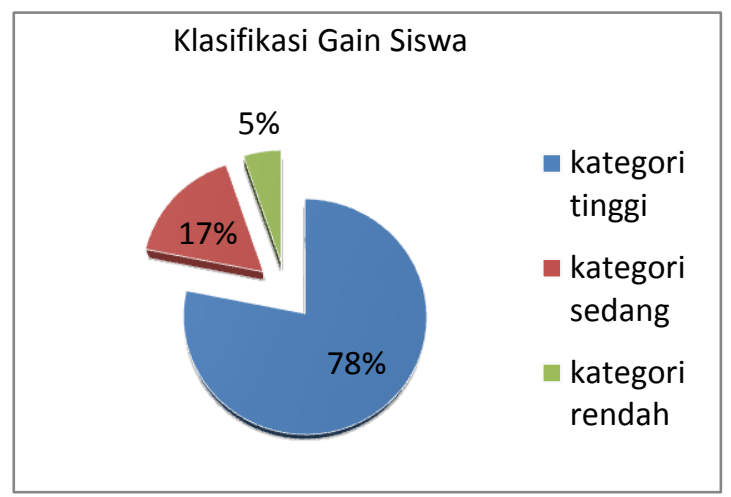

Gambar 7. Klasifikasi Perolehan Skor Gain

Berdasarkan hasil pre-test dan posttest siswa dilihat dari jumlah rata-rata indeks skor gain seluruh siswa kelas 2 yaitu sebesar 0,71. Artinya efektifitas produk yang dikembangkan berkategori tinggi.

Produk multimedia pembelajaran PAI materi tata cara sholat dengan menggunakan teknologi Adobe flash CS3 jika ditinjau dari segi jenis media pembelajaran merupakan alat audio sekaligus visual, yakni alat-alat yang dapat menghasilkan jenis multimedia pembelajaran seperti yang dikembangkan ini. Produk multimedia pembelajaran PAI materi tata cara sholat yang dikembangkan dapat dijadikan sebagai salah satu sumber belajar bagi siswa kelas 2 sekolah dasar, sehingga siswa lebih mudah mengkonstruksi pelajaran dan dengan demikian diharapkan pembelajaran PAI pada materi tata cara sholat menjadi lebih menarik dan bermakna.

Setelah dilakukan validasi oleh ahli materi maupun ahli media, evaluasi atau penilaian dari guru dan uji coba satu-satu, uji coba kelompok kecil serta uji coba lapangan terbukti bahwa penggunaan multimedia pembelajaran PAI materi tata cara sholat yang dikembangkan mempunyai kemampuan meningkatkan prestasi siswa. Dari hasil pre-test dan post-test terjadi peningkatan nilai atau peningkatan penguasaan keterampilan siswa terhadap materi tata cara sholat. Peningkatan nilai ini merupakan efek dari treatment yang di- lakukan yakni dengan melihat selisih antara hasil pre-test dengan hasil post-test.

Walaupun bukan merupakan sumber belajar yang utama, namun dengan pengunaan produk multimedia pembelajaran berbantuan komputer ini diharapkan dapat membantu memecahkan masalah belajar, baik sebagai sumber belajar alternatif maupun pelengkap. Dengan produk multimedia pembelajaran ini diharapkan pembelajaran pendidikan agama Islam pada materi tata cara sholat lebih menarik dan menimbulkan motivasi belajar siswa agar dapat meningkatkan keterampilan serta prestasi belajar siswa.

Keunggulannya adalah bahwa pembuatan produk multimedia pembelajaran ini menggunakan program Adobe Flash CS3 sehingga menghasilkan file yang tidak terlalu besar kapasitasnya. Materi yang disajikan dikemas dalam bentuk animasi bergerak yang memberikan simulasi gerakan sholat yang bisa ditiru oleh siswa. Keunggulan yang lain yaitu hasil produk multimedia pembelajaran PAI materi tata cara sholat yang dikembangkan ini mempunyai manfaat yang nyata, yaitu sampai saat ini belum adanya suatu multimedia pembelajaran interaktif untuk pembelajaran PAI materi tata cara sholat bagi siswa kelas 2 sekolah dasar. Hal ini yang menggembirakan peneliti yaitu banyaknya siswa yang ingin memiliki CD interaktif produk multimedia pembelajaran ini dalam proses uji coba.

Hasil penelitan ini sesuai dengan penelitian yang dilakukan oleh beberapa peneliti. Penelitian Kim \& Roth (2008, pp. 516-528) menunjukkan bahwa penerapan pembelajaran dengan mengaitkan ilmu pengetahuan, lingkungan, teknologi, dan masyarakat akan membuat siswa lebih baik.

\section{Simpulan dan Saran}

Simpulan

Berdasarkan hasil penelitian dan analisis data yang telah diuraikan, maka diperoleh kesimpulan dalam penelitian pengembangan ini sebagai berikut. Pertama, 
produk yang dihasilkan dalam penelitian dan pengembangan ini terbukti layak dan valid digunakan dalam proses pembelajaran ditinjau dari aspek materi, aspek pembelajaran, aspek tampilan dan aspek pemrograman. Hal ini dibuktikan dari hasil penilaian validasi ahli materi, penilaian validasi ahli media, dan penilaian guru mata pelajaran.

Kedua, respons siswa terhadap produk yang dikembangkan menunjukkan kesan atau tanggapan yang sangat baik yang dibuktikan dengan hasil kuesioner dalam penelitian. Ketiga, multimedia hasil pengembangan ini terbukti efektif digunakan sebagai bahan ajar. Kenaikan hasil belajar siswa pada uji keefektifan multimedia pembelajaran ini yaitu rerata sebesar 72,18 pada saat pre-test, sedangkan hasil belajar siswa pada saat post-test diperoleh rerata sebesar 91,49. Berdasarkan hasil tersebut diperoleh kenaikan skor rerata sebesar 0,71 poin yang termasuk dalam kategori "tinggi".

\section{Saran}

Berdasarkan hasil penelitian dan pengembangan dapat disarankan hal-hal sebagai berikut. Pertama, bagi siswa diharapkan dalam proses pembelajaran dapat memanfaatkan multimedia pembelajaran interaktif tata cara sholat dengan baik agar dapat lebih meningkatkan penguasaan materi tata cara sholat dan lebih terampil dalam melakukan gerakan sholat sesuai dengan tata cara yang baik dan benar seperti disajikan pada animasi gerakan sholat pada multimedia pembelajaran tata cara sholat yang dikembangkan.

Kedua, bagi guru diharapkan bisa mengembangkan multimedia pembelajaran tata cara sholat yang dilengkapi dengan komponen yang lebih lebih lengkap dan menarik. Guru juga diharapkan bisa memanfaatkan fasilitas yang tersedia di ruang kelas maupun laboratorium komputer yang dimiliki sekolah serta menyesuaikan waktu dan tujuan dalam menyampaikan materi dengan penggunaan multimedia yang tepat, serta bisa memberikan langkah- langkah dan pengawasan yang jelas di dalam menggunakan produk multimedia pembelajaran interaktif ini.

\section{Daftar Pustaka}

Borg, W.R., \& Gall, M.D. (1983). Educational research: An introduction. (4th ed) New York \& London: Longman.

Majid, Abdul (2012). Belajar dan pembelajaran pendidikan agama Islam. Bandung: Remaja Rosdakarya.

Budiningsih, Asri .C. (2012). Belajar dan pembelajaran. Jakarta: Rineka Cipta.

Arifin, H.M. (2006). Ilmu pendidikan islam: tinjauan teoritis dan praktis berdasarkan pendekatan interdisipliner. Jakarta: Bumi Aksara.

Crozat, S., Hu, O. \& Trigano, P. (1999, Juli). A method for evaluating multimedia learning software. Makalah disajikan dalam IEEE International Conference on Multimedia Computing and System, di Florence;

Dick, W., Carey, L., Carey, J.O. (2005). The systematic design of instruction ( $\left.6^{\text {th ed }}\right)$. Boston: Scott, Pearson A.B.

Gafur, Abdul. (2012). Desain pembelajaran: konsep, model, dan aplikasinya dalam perencanaan pelaksanaan pembelajaran. Yogyakarta: Penerbit Ombak.

Kyriacou, C. (2009). Effective teaching in schools: Theory and practice. London: Nelson Thornes.

Mayer, R.E. (eds). (2009). Multimedia learning: prinsip-prinsip dan aplikasi. Yogyakarta: Pustaka Pelajar.

Newby, Timothy. J., et.al, (2000). Instructional technology for teaching and learning: designing instruction, integrating computers, and using media. New Jersey: Prentice-Hall.

Smaldino, S.E., Lowther, D.L., \& Russell, J.D. (2008). Instructional technology and media for learning. (9th ed): teknologi pembelajaran dan media pembelajaran dan media untuk belajar. (Terjemahan Arif Rahman). New Jersey: Pearson Prentice Hall. 